\title{
Erratum: Lopez, J.E., et al. Tick-Borne Relapsing Fever Spirochetes in the Americas. Vet. Sci. 2016, 3, 16
}

\author{
Job E. Lopez ${ }^{1,2, *}$, Aparna Krishnavajhala ${ }^{1}$, Melissa N. Garcia ${ }^{1}$ and Sergio Bermudez ${ }^{3}$ \\ 1 Department of Pediatrics, National School of Tropical Medicine, Baylor College of Medicine, \\ Houston, TX 77030, USA; Aparna.Krishnavahjala@bcm.edu (A.K.); mnolan@bcm.edu (M.N.G.) \\ 2 Department of Molecular Virology and Microbiology, Baylor College of Medicine, Houston, TX 77030, USA \\ 3 Departamento de Investigación en Entomología Médica, Instituto Conmemorativo Gorgas de Estudios de la \\ Salud, City of Panama PO Box 816-02593, Panama; bermudezsec@gmail.com \\ * Correspondence: job.lopez@bcm.edu; Tel.: +1-832-824-0557
}

Received: 19 November 2019; Accepted: 3 December 2019; Published: 4 December 2019

The authors wish to make the following correction to this paper [1]: The author name "Aparna Krishnavahjala" should be "Aparna Krishnavajhala".

We apologize for any inconvenience caused to the readers.

\section{Reference}

1. Lopez, J.E.; Krishnavajhala, A.; Garcia, M.N.; Bermudez, S. Tick-borne relapsing fever spirochetes in the Americas. Vet. Sci. 2016, 3, 16. [CrossRef] [PubMed]

(C) 2019 by the authors. Licensee MDPI, Basel, Switzerland. This article is an open access article distributed under the terms and conditions of the Creative Commons Attribution (CC BY) license (http://creativecommons.org/licenses/by/4.0/). 